\title{
Influence of the Matrix Structure of the Modulator and Detector on the Optical Spectrum Analyzer Output Signal
}

\author{
Kolobrodov, V. H., Tymchik, G. S., Mykytenko, V. I., Kolobrodov, M. S., Lutsiuk, M. M. \\ National Technical University of Ukraine "Igor Sikorsky Kyiv Polytechnic Institute" \\ E-mail: thermo@ukr.net
}

\begin{abstract}
In this article, we investigate the physical and mathematical model of a coherent optical spectrum analyzer (COSA), which uses a matrix light modulator and a matrix detector as input and output devices. This model allows to define distortions in the output signal of the spectrum analyzer and the error in determining the signal spatial frequency. The study of this model showed that form of the signal at the COSA's output depends on the pixels sizes of modulator and detector matrices, as well as on the aberrations of the Fourier lens entrance pupil diameter. The output signal is a convolution of an ideal input signal spectrum with a discrete spatial transmission spectrum of the modulator, which is followed by convolution with a discrete sensitivity of the matrix detector. This means that the spectrum of the signal under investigation is distorted by the spatial spectrum of the modulator and the matrix structure of the matrix detector. An important feature of the signal is its independence from the phase shift, which is caused by the displacement of the modulator center relative to the optical axis of the spectrum analyzer. The output signal of COSA consists of an infinite number of diffraction maximum, each of which has three maximum, the distance between which is proportional to the spatial frequency of the test signal. The position (frequency) of the maximum is determined by the pixel size, and their width by the size of the modulator. Obtain the formulas for determining the spatial frequency of the test signal, which differ substantially from the traditional formula and depend on the position of the central and lateral maximum in the diffraction maximum. The error in measuring the frequency depends on the size of the detector pixel, focal length of the Fourier lens, and the modulator matrix size. Developed the method for determining the error in measuring the spatial frequency of a harmonic signal. The error is defined as the difference between the true frequency corresponding to the position of the center of the diffraction maximum and the measured frequency corresponding to the position of the pixel center which has the maximum signal.
\end{abstract}

Key words: digital optoelectronic spectrum analyzer; matrix light modulator; matrix detector; spatial spectrum of the image

\section{Introduction}

Optical methods of information processing have significant advantages in comparison with electronic systems, primarily due to the instant processing of two-dimensional arrays of information at the speed of light [1-3]. Most optical processors use coherent spectrum analyzers, which are designed to convert two-dimensional distribution of the field amplitude into the spatial spectrum of this distribution $[4,5]$. The efficiency limit of a coherent optical spectrum analyzers (COSA) depends on the spatial resolution and speed of input and output devices $[6,7]$. The matrix spatial light modulators (SLM) with transmission of pixels, which defined by the test signal, are applied as devices for input of signals in modern COSA to process optical signals in real time and increase the measurement accuracy $[8,9]$. The output signal of the device is registered with a matrix detector
(MD) of light (such as digital camera or webcam) with further computer processing, which significantly extends functional capabilities of the COSA $[9,10]$.

There are many monographs and articles, where the features of using SLM or matrix detector in optoelectronic systems are explored $[10,11]$. At the same time, there is a lack of scientific and technical information about the joint effect of the matrix structure of SLM and MD on the generalized characteristics of COSA.

\section{Problem formulation}

The purpose of the article is to develop physicmathematical model of coherent optical spectrum analyzer which has the space-time matrix light modulator and matrix detector. This model allows to determine the distortions in input signal and 
inaccuracies in defining spatial frequency of signal input signal is determined by the function [11] which is measured.

\section{Physical and mathematical model of digital coherent spectrum analyzer}

A coherent optical spectrum analyzer classic scheme (Fig. 1) consists of spatial light modulator, Fourier-lens and matrix detector [1,2]. The light modulator is located in the front focal plane of the Fourier-lens and has an amplitude transmission coefficient $t_{m}\left(x_{1}, y_{1}\right)$ which is determined by the matrix structure of the modulator and the video signal of the image. The modulator is illuminated by a plane monochromatic wave with the amplitude $V_{p}$ and forms the field distribution $V_{1}\left(x_{1}, y_{1}\right)$ behind the modulator. The lens realizes a two-dimensional transformation of the amplitude of this field and forms in the back focal plane a two-dimensional spectrum $\tilde{V}_{1}\left(\nu_{x}, \nu_{y}\right)$ of the function $V_{1}\left(x_{1}, y_{1}\right)$. The matrix detector converts the intensity of the field $I_{3}\left(x_{3}, y_{3}\right)$ into video signal $u_{D}\left(x_{3}, y_{3}\right)$. If the COSA is used in the spectral filtering system of the optical signal, i.e. when the spectrum of the signal $\tilde{V}_{1}\left(\nu_{x}, \nu_{y}\right)$ is multiplied by the transfer function of the filter $H_{f}\left(\nu_{x}, \nu_{y}\right)$ with the subsequent Fourier transform, the second SLM is placed in the back focal plane of the lens, the transmission of which is determined by the function $H_{f}\left(\nu_{x}, \nu_{y}\right)$.

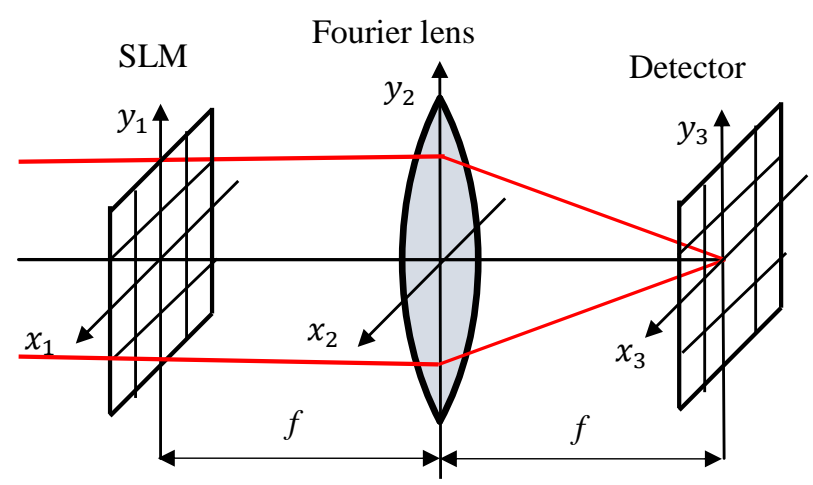

Fig. 1. Digital coherent optical spectrum analyzer scheme

Let's consider the models of the separate components of a coherent spectrum analyzer.

The spatial light modulator (SLM) has a matrix structure. An amplitude transmission coefficient of it's pixels corresponds to an amplitude of the input (test) optical signal. Therefore, such devices allow to enter optical signals, which are varying in time and space, into the processor. The matrix structure of the SLM is $X_{m} \times Y_{m}$ size and the period of $V_{m} \times W_{m}$ (Fig. 2). Each pixel has a transparent zone $v_{m} \times w_{m}$. The amplitude coefficient of such a modulator in the absence of an

$$
\begin{aligned}
& t_{m 0}\left(x_{1}, y_{1}\right)=\left\{\operatorname{rect}\left(\frac{x_{1}-x_{1 m 0}}{v_{m}}\right) *\right. \\
& \left.*\left[\frac{1}{V_{m}} \operatorname{comb}\left(\frac{x_{1}-x_{1 m 0}}{V_{m}}\right) \operatorname{rect}\left(\frac{x_{1}-x_{1 m 0}}{X_{m}}\right)\right]\right\} \times \\
& \quad \times\left\{\operatorname{rect}\left(\frac{y_{1}-y_{1 m 0}}{w_{m}}\right) *\right. \\
& \left.*\left[\frac{1}{W_{m}} \operatorname{comb}\left(\frac{y_{1}-y_{1 m 0}}{W_{m}}\right) \operatorname{rect}\left(\frac{y_{1}-y_{1 m 0}}{Y_{m}}\right)\right]\right\}= \\
& \quad=t_{m 0 x}\left(x_{1}\right) t_{m 0 y}\left(y_{1}\right),
\end{aligned}
$$

where $x_{1 m 0}, y_{1 m 0}$ are coordinates of the center of zero (central) pixel of the modulator with respect to the origin of the coordinate system $x_{1} y_{1}$, which determine the displacement of the modulator matrix center relative to the COSA optical axis;

$\operatorname{rect}(z)-\operatorname{rect-function}, \operatorname{rect}(z)=\left\{\begin{array}{l}1, \text { when }|z| \leq 1 / 2 \\ 0, \text { when }|z|>1 / 2\end{array}\right.$ $\operatorname{comb}(\mathrm{z})-\mathrm{comb}-$ function, $\operatorname{comb}(\mathrm{z})=\sum_{n=-\infty}^{\infty} \delta(z-n)$. $Y_{m} Y_{m}$
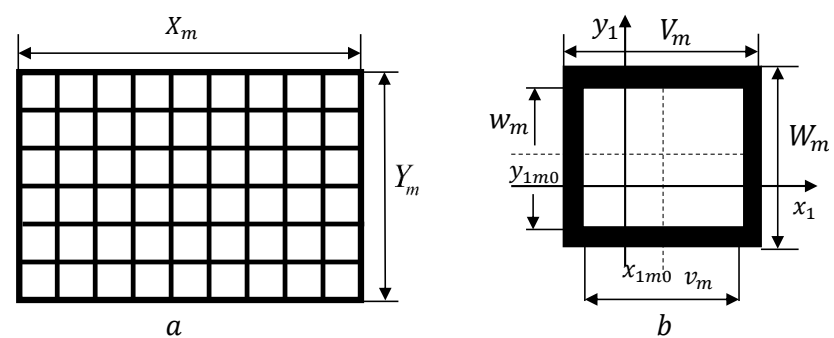

Fig. 2. A model of the matrix spatial light modulator:

(a) is the matrix; (b) is the center pixel

In the formula (1) the expressions in square brackets determine the periodic structure of the matrix $X_{m} \times Y_{m}$.

Let suppose an optical signal (a video signal) is input to the modulator and is normalized to $u_{s n}\left(x_{1}, y_{1}\right)=u_{s}\left(x_{1}, y_{1}\right) / u_{s, \max }\left(x_{1}, y_{1}\right)$. Then it is converted to the amplitude transmittance coefficient of the modulator $t_{s}\left(x_{1}, y_{1}\right)$.

Then the amplitude transmission coefficient of the modulator can be represented in the form

$$
t_{m}\left(x_{1}, y_{1}\right)=t_{m 0}\left(x_{1}, y_{1}\right) t_{s}\left(x_{1}, y_{1}\right) .
$$

After diffraction on the matrix structure light enters the entrance aperture of the lens.

The Fourier-lens is designed to form the spatial spectrum of the input optical signal. If SLM is located in the front focal plane $x_{1} y_{1}$ of the Fourier-lens and is illuminated by a plane wave with amplitude $V_{p}$ (Fig. 1), then the distribution of the field amplitude $x_{3} y_{3}$ in back focal plane is described by the expression $[1,2]$

$$
\begin{aligned}
V\left(x_{3}, y_{3}\right)=\frac{V_{p}}{j \lambda f} \iint_{-\infty}^{\infty} t_{m}\left(x_{1}, y_{1}\right) * \\
\\
\quad * e^{-j \frac{2 \pi}{\lambda f}\left(x_{3} x_{1}+y_{3} y_{1}\right)} d x_{1} d y_{1},
\end{aligned}
$$


where $f$ is a focal length of the Fourier-lens.

Analysis of expression (3) shows that the complex amplitude of the light field in the back focal plane of the Fourier-lens, up to a constant factor $V_{p} / j \lambda f$, is the spatial spectrum of the modulator amplitude transmission coefficient $t_{m}\left(x_{1}, y_{1}\right)$ with spatial frequencies:

$$
\nu_{x}=\frac{x_{3}}{\lambda f} ; \quad \nu_{y}=\frac{y_{3}}{\lambda f} .
$$

To model the Fourier-lens following characteristics were used: the focal length $f$, entrance aperture diameter $D_{p}$, point spread function $(\mathrm{PSF}) h_{o}(x, y)$. For a diffraction-limited Fourier lens, its PSF is determined by the diameter of the entrance aperture and has the form $[1,2]$

$$
\begin{aligned}
h_{o}\left(x_{3}, y_{3}\right)=\iint_{-\infty}^{\infty} P_{o}\left(\lambda f \nu_{x}, \lambda f \nu_{y}\right) . \\
\cdot e^{-j 2 \pi\left(x_{3} \nu_{x}+y_{3} \nu_{y}\right)} d \nu_{x} d \nu_{y},
\end{aligned}
$$

where $P_{o}$ is a pupil function.

The matrix detector (MD) is used to record the intensity of the light field $I\left(x_{3}, y_{3}\right)=\left|V\left(x_{3}, y_{3}\right)\right|^{2}$ in the focal plane of the Fourier-lens.

The signal at the MD output is determined by the convolution of the functions

$$
u_{D}\left(x_{3}, y_{3}\right)=I\left(x_{3}, y_{3}\right) * * R_{D}\left(x_{3}, y_{3}\right),
$$

where $R_{D}\left(x_{3}, y_{3}\right)$ is the spectral sensitivity of the detector at the wavelength $\lambda u p$ of the laser radiation and $* *$ is an operator of two-dimensional convolution.

For modeling MD we will use following features:

1. matrix format $p_{D} \times q_{D}$;

2. pixel size $v_{D} \times w_{D}, m k m^{2}$;

3. detector matrix structure period $V_{D} \times W_{D}$, $\mathrm{mkm}^{2}$;

4. spectral sensitivity $R_{D}, V /(l x \cdot s)$;

5 . accumulation time $t_{i}$, sec.

Let's present the sensitivity of the MD $R_{D}\left(x_{3}, y_{3}\right)$ similarly to the modulator transmission function (1)

$$
\begin{aligned}
& R_{D}\left(x_{3}, y_{3}\right)=R_{D}\left\{\operatorname{rect}\left(\frac{x_{3}-x_{3 D 0}}{v_{D}}\right) *\right. \\
& \left.*\left[\frac{1}{V_{D}} \operatorname{comb}\left(\frac{x_{3}-x_{3 D 0}}{V_{D}}\right) \operatorname{rect}\left(\frac{x_{3}-x_{3 D 0}}{X_{D}}\right)\right]\right\} \times \\
& \quad \times\left\{\operatorname{rect}\left(\frac{y_{3}-y_{3 D 0}}{w_{D}}\right) *\right. \\
& \left.*\left[\frac{1}{W_{D}} \operatorname{comb}\left(\frac{y_{3}-y_{3 D 0}}{W_{D}}\right) \operatorname{rect}\left(\frac{y_{3}-y_{3 D 0}}{Y_{D}}\right)\right]\right\}= \\
& \quad=R_{D x}\left(x_{3}\right) R_{D y}\left(y_{3}\right),
\end{aligned}
$$

where $x_{1 D 0}, y_{1 D 0}$ are the coordinates of the center of zero (central) pixel of the MD relative to the origin of the coordinate system $x_{3} y_{3}$, which determine the center of the modulator matrix relative to COSA optical axis.

\section{The output signal of the matrix detector}

The distribution of the field amplitude in the back focal plane of the Fourier-lens, which is determined by integral (3), is valid for an ideal lens with an infinite entrance aperture. If the lens has PSF $h_{o}\left(x_{3}, y_{3}\right)$, then the real amplitude of the field $V_{r}\left(x_{3}, y_{3}\right)$ in the plane $x_{3}, y_{3}$ is determined by the convolution of the functions

$$
V_{r}\left(x_{3}, y_{3}\right)=V\left(x_{3}, y_{3}\right) * * h_{o}\left(x_{3}, y_{3}\right) .
$$

Then the video signal at the MD output is determined by convolution (6), which can be represented as

$$
\begin{aligned}
& u_{D}\left(x_{3}, y_{3}\right)= \\
& =\left\{\left|V\left(x_{3}, y_{3}\right) * h_{o}\left(x_{3}, y_{3}\right)\right|^{2} * R_{D}\left(x_{3}, y_{3}\right)\right\}= \\
& =\frac{I_{p}}{\lambda^{2} f^{2}}\left\{\left[F\left\{t_{m}\left(x_{1}, y_{1}\right)\right\} * h_{o}\left(x_{3}, y_{3}\right)\right]^{2} *\right. \\
& \left.* R_{D}\left(x_{3}, y_{3}\right)\right\}=\frac{I_{p}}{\lambda^{2} f^{2}}\left\{\left[F\left\{t_{m 0}\left(x_{1}, y_{1}\right) t_{s}\left(x_{1}, y_{1}\right)\right\} *\right.\right. \\
& \left.\left.\quad * h_{o}\left(x_{3}, y_{3}\right)\right]^{2} * R_{D}\left(x_{3}, y_{3}\right)\right\},
\end{aligned}
$$

where $F\{\}$ is an operator of a two-dimensional Fourier transform and $I_{p}=\left|V_{p}\right|^{2}$ is an intensity of the laser beam which illuminates the modulator. After substituting functions (1), (5) and (7) in (9), we can determine the general equation for calculating the video signal at the output of the spectrum analyzer. For a preliminary analysis of the function (9) there are series of approximations:

1. For the diffraction-limited optical system of the Fourier-lens, the radius of the spread circle is equal to the radius of the Airy circle [1]

$$
r_{E}=1,22 \lambda \frac{f}{D_{p}} .
$$

If the diaphragm number of the lens is $f / D_{p}=$ 2 and the wavelength of the laser radiation is $\lambda u p=$ $0.63 \mu u p m$, then the diameter of the lens scattering circle $2 r_{E}=1,5 \mu u p m$ will be much smaller than the MD pixel size $V_{D}=7 \mu u p m$. In this case, the PSF (5) can be viewed as a point (delta function).

2. In order to simplify the mathematical transformations, we consider the one-dimensional case. Therefore, the functions (1) and (7) have the form

$$
\begin{aligned}
& t_{m 0 x}\left(x_{1}\right)=\operatorname{rect}\left(\frac{x_{1}-x_{1 m 0}}{v_{m}}\right) * \\
& *\left[\frac{1}{V_{m}} \operatorname{comb}\left(\frac{x_{1}-x_{1 m 0}}{V_{m}}\right) \operatorname{rect}\left(\frac{x_{1}-x_{1 m 0}}{X_{m}}\right)\right],
\end{aligned}
$$




$$
\begin{aligned}
& R_{D x}\left(x_{3}\right)=R_{D}\left\{\operatorname{rect}\left(\frac{x_{3}-x_{3 D 0}}{v_{D}}\right) *\right. \\
& \left.*\left[\frac{1}{V_{D}} \operatorname{comb}\left(\frac{x_{3}-x_{3 D 0}}{V_{D}}\right) \operatorname{rect}\left(\frac{x_{3}-x_{3 D 0}}{X_{D}}\right)\right]\right\} .
\end{aligned}
$$

Then expression (9) will have the form

$$
\begin{aligned}
& u_{D}\left(x_{3}\right)=\left\{\left|V\left(x_{3}\right)\right|^{2} * R_{D}\left(x_{3}\right)\right\}= \\
& =\frac{I_{p}}{\lambda^{2} f^{2}}\left\{\left|F\left\{t_{m 0 x}\left(x_{1}\right) t_{s}\left(x_{1}\right)\right\}\right|^{2} * R_{D}\left(x_{3}\right)\right\} .
\end{aligned}
$$

Let's define the spatial spectrum of the modulator transmission function $t_{m}\left(x_{1}\right)$ in the presence of the input signal $t_{s}\left(x_{1}\right)$

$$
\begin{aligned}
& \tilde{t}_{m}\left(\nu_{x}\right)=\tilde{t}_{m}\left(\frac{x_{3}}{\lambda f}\right)=F\left\{t_{m}\left(x_{1}\right)\right\}= \\
& =F\left\{t_{m 0}\left(x_{1}\right) t_{s}\left(x_{1}\right)\right\}=\tilde{t}_{m 0}\left(\nu_{x}\right) * \tilde{t}_{s}\left(\nu_{x}\right),
\end{aligned}
$$

where $\tilde{t}_{s}\left(\nu_{x}\right)=F\left\{t_{m}\left(x_{1}\right)\right\}$ is a spectrum of the input signal and $\tilde{t}_{m 0}\left(\nu_{x}\right)$ is modulator spatial transmission spectrum in the absence of an input signal, which is determined by the function $[1,11]$

$$
\begin{gathered}
\tilde{t}_{m 0 x}\left(\nu_{x}\right)=F\left\{t_{m 0 x}\left(x_{1}\right)\right\}=F\left\{\operatorname{rect}\left(\frac{x_{1}-x_{1 m 0}}{v_{m}}\right) *\right. \\
\left.*\left[\frac{1}{V_{m}} \operatorname{comb}\left(\frac{x_{1}-x_{1 m 0}}{V_{m}}\right) \operatorname{rect}\left(\frac{x_{1}-x_{1 m 0}}{X_{m}}\right)\right]\right\}= \\
=v_{m} \operatorname{sinc}\left(v_{m} \nu_{x}\right) e^{-j 2 \pi x_{1 m 0} \nu_{x}} \times \\
\times\left\{\left[\operatorname{comb}\left(V_{m} \nu_{x}\right)\right] * X_{m} \operatorname{sinc}\left(X_{m} \nu_{x}\right) e^{-j 2 \pi x_{1 m 0} \nu_{x}}\right\}= \\
=v_{m} \operatorname{sinc}\left(v_{m} \nu_{x}\right) e^{-j 4 \pi x_{1 m 0} \nu_{x}} \cdot \frac{\sin \left(\pi X_{m} \nu_{x}\right)}{\sin \left(\pi V_{m} \nu_{x}\right)},
\end{gathered}
$$

where $\sin c(z)=\sin (\pi z) / \pi z$.

Analysis of the function (15) shows that the diffracted beams from adjacent pixels will be amplified if the condition of the main maximum is fulfilled $V_{m} \nu_{x}=$ $i$, where $i=0, \pm 1, \ldots$ is a maximum number. Then the expression (15) for the $i$-th maximum has the form [1]

$$
\begin{aligned}
& \tilde{t}_{m 0 x}\left(\nu_{x, \max , i}=\frac{i}{V_{m}}\right)= \\
& =v_{m} \operatorname{sinc}\left(v_{m} \frac{i}{V_{m}}\right) \exp \left(-j 4 \pi x_{1 m 0} \frac{i}{V_{m}}\right) \frac{X_{m}}{V_{m}}
\end{aligned}
$$

It follows from (15) and (16) that the spatial spectrum of such modulator is an infinite number of diffraction maximums which positions (frequencies) are determined by the pixel size $V_{m}$. The width of diffraction maximums are determined by the size $X_{m}$ of the modulator. The amplitude of the field in the diffraction maximum is a complex function whose modulus equals is $\frac{v_{m} X_{m}}{V_{m}} \operatorname{sinc}\left(v_{m} \frac{i}{V_{m}}\right)$ and the phase is $-4 \pi x_{1 m 0} \frac{i}{V_{m}}$. The maximum value of the amplitude is located in the central maximum, when $i=0$. With increasing of diffraction order $i$, the amplitude of the maxima decreases. Taking into account expressions (14) and (15), the signal at the output of the detector is equal to

$$
\begin{gathered}
u_{D}\left(x_{3}\right)= \\
=\frac{I_{p}}{\lambda^{2} f^{2}}\left\{\left[\left|\tilde{t}_{m 0 x}\left(\nu_{x}\right) * \tilde{t}_{s}\left(\nu_{x}\right)\right|^{2}\right] * R_{D}\left(x_{3}\right)\right\}= \\
=\frac{I_{p}}{\lambda^{2} f^{2}}\left\{\left[v_{m} \operatorname{sinc}\left(v_{m} \nu_{x}\right) \frac{\sin \left(\pi X_{m} \nu_{x}\right)}{\sin \left(\pi V_{m} \nu_{x}\right)} * \tilde{t}_{s}\left(\nu_{x}\right)\right]^{2} *\right. \\
\left.* R_{D}\left(x_{3}\right)\right\} .
\end{gathered}
$$

Analysis of expression (17) shows that the signal at the spectrum analyzer output is a convolution of the ideal signal spectrum $\tilde{t}_{s}\left(\nu_{x}\right)$ with a discrete spatial transmission spectrum of the modulator $\tilde{t}_{m 0 i}$, which is followed by convolution with discrete sensitivity of the matrix detector. This means that the spectrum of the test signal is distorted by the spatial spectrum of the modulator and by the matrix structure of the matrix detector. An important feature of the signal is its independence from the phase shift $4 \pi x_{1 m 0} \frac{i}{V_{m}}$, which is caused by the displacement of the modulator center from the spectrum analyzer optical axis.

\section{The analysis of harmonic signal spectrum}

As an example of calculation of the MD output signal, let's consider the harmonic input signal, which is modeled by the function

$$
t_{s}\left(x_{1}\right)=\frac{1}{2}+t_{s a} \cos \left(2 \pi \nu_{s} x_{1}\right)
$$

where $t_{s a}$ is an amplitude of the signal and $\nu_{s}$ is a frequency of the signal.

The spatial spectrum of such signal is determined by the function [1]

$$
\tilde{t}_{s}\left(\nu_{x}\right)=\frac{1}{2} \delta\left(\nu_{x}\right)+\frac{t_{s a}}{2} \delta\left(\nu_{x}-\nu_{s}\right)+\frac{t_{s a}}{2} \delta\left(\nu_{x}-\nu_{s}\right) .
$$

Let's substitute the function (19) into the expression (17) and use the filtering property of the delta function 


$$
\begin{gathered}
u_{D}\left(x_{3}\right)=\frac{I_{p}}{\lambda^{2} f^{2}}\left\{\left[v_{m} \operatorname{sinc}\left(v_{m} \nu_{x}\right) \frac{\sin \left(\pi X_{m} \nu_{x}\right)}{\sin \left(\pi V_{m} \nu_{x}\right)} *\right.\right. \\
\left.*\left[\frac{\delta\left(\nu_{x}\right)}{2}+\frac{t_{s a}}{2} \delta\left(\nu_{x}-\nu_{s}\right)+\frac{t_{s a}}{2} \delta\left(\nu_{x}-\nu_{s}\right)\right]\right]^{2} * \\
\left.* R_{D}\left(x_{3}\right)\right\}= \\
+\frac{I_{p}}{\lambda^{2} f^{2}}\left\{\left[\frac{1}{2} v_{m} \operatorname{sinc}\left(v_{m} \nu_{x}\right) \frac{\sin \left(\pi X_{m} \nu_{x}\right)}{\sin \left(\pi V_{m} \nu_{x}\right)}+\right.\right. \\
+\frac{t_{s a}}{2} v_{m} \operatorname{sinc}\left[v_{m}\left(\nu_{x}-\nu_{s}\right)\right] \frac{\sin \left[\pi X_{m}\left(\nu_{x}-\nu_{s}\right)\right]}{\sin \left[\pi V_{m}\left(\nu_{x}-\nu_{s}\right)\right]}+ \\
+\frac{t_{s a}}{2} v_{m} \operatorname{sinc}\left[v_{m}\left(\nu_{x}+\nu_{s}\right)\right] \\
\left.\left.\quad \frac{\sin \left[\pi X_{m}\left(\nu_{x}+\nu_{s}\right)\right]}{\sin \left[\pi V_{m}\left(\nu_{x}+\nu_{s}\right)\right]}\right]^{2} * R_{D}\left(x_{3}\right)\right\} .
\end{gathered}
$$

From the expression (20) it turns out that the signal at the MD output consists of an infinite number of diffraction maximums and each of them has three maximums displaced relatively to each other.

Let's determine the distance between the maximums and their width. An investigation of the function (20) shows that the positions of the central $x_{3, \max , i, 0}$ and lateral $x_{3, \max , i, \pm 1}$ maximums in the $i$-th diffraction order can be found from the conditions:

$$
\begin{aligned}
& V_{m} \nu_{x, \max , i, 0}=i ; \quad \Rightarrow \\
& \Rightarrow \quad V_{m} \frac{x_{3, \max , i, 0}}{\lambda f}=i ; \quad \Rightarrow \\
& \Rightarrow \quad x_{3, \max , i, 0}=\frac{i \lambda f}{V_{m}} ;
\end{aligned}
$$

and

$$
\begin{aligned}
V_{m}\left(\nu_{x, \max , i, \pm 1} \pm \nu_{s}\right)=i ; \Rightarrow & \\
\Rightarrow \quad & V_{m}\left(\frac{x_{3, \max , i, \pm 1}}{\lambda f} \pm \nu_{s}\right)=i ; \Rightarrow \\
\Rightarrow \quad & x_{3, \max , i, \pm 1}=\lambda f\left(\frac{i}{V_{m}} \mp \nu_{s}\right) .
\end{aligned}
$$

From the expressions (21) and (22), two methods for determining the spatial frequency $\nu_{s}$ of the test signal could be suggested:

$$
\begin{aligned}
& \text { 1. } \nu_{s}=\frac{x_{3, \max , i,+1}-x_{3, \max , i,-1}}{2 \lambda f} \\
& \text { 2. } \nu_{s}=\frac{x_{3, \max , i, 0}-x_{3, \max , i,-1}}{\lambda f} .
\end{aligned}
$$

The greatest amplitude has a diffraction maximum of the first order, when

$i=1$. The width of this maximum $\delta x_{3}$ can be found from expression (20), when condition is fulfilled

$$
\frac{\sin \left(\pi X_{m} \nu_{x}\right)}{\sin \left(\pi V_{m} \nu_{x}\right)}=0
$$

The solution of this equation describes width of the maximum

$$
\delta \nu_{x}=\frac{\delta x_{3}}{\lambda f}=\frac{2}{X_{m}} ; \Rightarrow \delta x_{3}=\frac{2 \lambda f}{X_{m}} .
$$

Similar result can be obtained along the coordinate $y_{3}$.

Thus, the diffraction maximum can be considered as a rectangle of size $\delta x_{3} \times \delta y_{3}$, which is projected onto the matrix structure (7) of the detector.

The center of this rectangle has coordinates for the first-order central maximum (Fig. 3)

$$
x_{3, \max , 1,0}, y_{3, \max , 1,0}=\frac{\lambda f}{V_{m}}, \frac{\lambda f}{V_{m}} .
$$

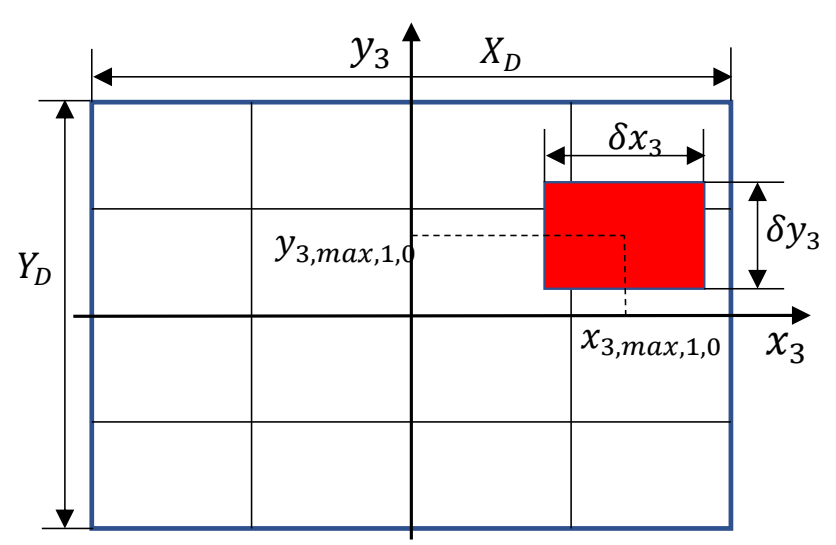

Fig. 3. The position of the diffraction maximum on the detector array

As a mathematical model of such maximum, we'll use illumination function

$$
\begin{aligned}
E\left(x_{3}, y_{3}\right)= & E_{\max , 1,0} \cdot \\
& \cdot \operatorname{rect}\left(\frac{x_{3}-x_{3, \max , 1,0}}{\delta x_{3}}\right) . \\
& \cdot \operatorname{rect}\left(\frac{y_{3}-y_{3, \max , 1,0}}{\delta y_{3}}\right),
\end{aligned}
$$

where $E_{\max , 1,0}$ is an illumination at the center of the diffraction maximum.

Taking into account the functions (7) and (28), the signal at the MD output for the one-dimensional case is equal to

$$
\begin{gathered}
u_{D, \text { max }, 1,0}\left(x_{3}\right)=E\left(x_{3}\right) * R_{D}\left(x_{3}\right)= \\
=E_{\text {max }, 1,0} \operatorname{rect}\left(\frac{x_{3}-x_{3, \max , 1,0}}{\delta x_{3}}\right) * \\
* R_{D}\left\{\operatorname { r e c t } ( \frac { x _ { 3 } - x _ { 3 D 0 } } { v _ { D } } ) * \left[\frac{1}{V_{D}} \operatorname{comb}\left(\frac{x_{3}-x_{3 D 0}}{V_{D}}\right)\right.\right. \\
\left.\left.\operatorname{rect}\left(\frac{x_{3}-x_{3 D 0}}{X_{D}}\right)\right]\right\} . \quad(29)
\end{gathered}
$$

Fig. 4 shows the signal at the MD output, which is formed by the diffraction maximum for different sizes of the maximum and the pixel, when $V_{D} \approx v_{D}$. 

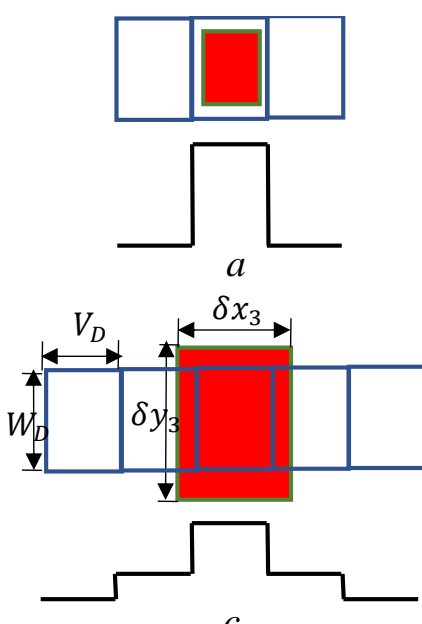

$C$
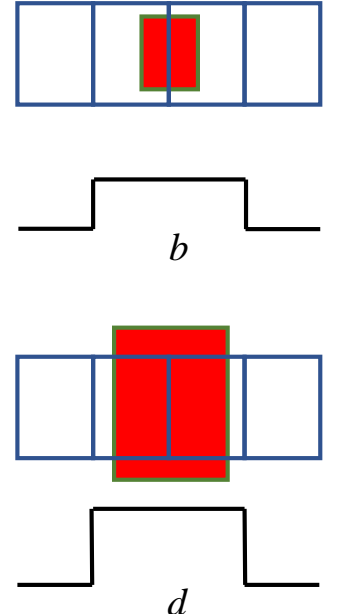

$d$

Fig. 4. The shape of the signal from the diffraction maximum as a function of its size and position on the

MD: (a), (b) $-\delta x_{3}<V_{D}$; (c), (d) $-\delta x_{3}=1,5 V_{D}$

In cases $a$ and $c$, the calculation of the spatial frequency for the central maximum is carried out according to formula (21), which has the form

$$
\nu_{x, \max , i, 0}=\frac{V_{D} N+0,5 V_{D}}{\lambda f},
$$

where $N$ is a number of pixels from the optical axis till to the diffraction maximum. In this case, the normalized amplitude of the maximum signal is 1.0 and 0.44 , respectively.

In cases $b$ and $d$, the spatial frequency is calculated by formula (21), which has the form

$$
\nu_{x, \max , i, 0}=\frac{V_{D} N}{\lambda f} .
$$

In this case, the normalized amplitude of the maximum signal is 0.5 and 0.33 , respectively.

Analysis of function (29) shows that the MD output signal, which corresponds to the diffraction maximum, depends on its position $x_{3, \max , 1,0}$ on the detector array (matrix), as well as on the detector $V_{D}$ pixel sizes and the maximum width $\delta x_{3}$.

After recovering the image [11], or corresponding processing of signals from individual pixels, it is possible to determine the position of the center of the maximum $x_{3, \max , 1,0}$, with sufficient accuracy, and determine the signal frequency from formulas (23) or (24). Using (20), we can also calculate the amplitude of the signal $t_{s a}$.

Let's consider a technique of definition inaccuracies when measuring harmonic signal spatial frequency $\delta \nu_{x m}$. We define it as

$$
\delta \nu_{x m}=\nu_{x 0}-\nu_{x m},
$$

where $\nu_{x 0}$ is a true frequency, which corresponds to the position of the center of the diffraction maximum and $\nu_{x m}$ is a measured frequency, which corresponds to the position of the center of the pixel, which has maximum signal.
In the $x_{3} y_{3}$ plane, expression (32) according to (4) has the form (Fig. 5a)

$$
\delta x_{3 m}=x_{30}-x_{3 m} .
$$

According to (29), the output signal of the pixel of the MD $u_{D, \max }\left(x_{3}^{\prime}\right)$ is a convolution between the area of the diffraction maximum and the area of the pixel (Fig. 5, a).

From the graph of the function $u_{D, \max }\left(x_{3}^{\prime}\right)$, shown in Fig. 5, $b$, we find the maximum displacement between the centers of the diffraction maximum and the pixel at which the signal has a maximum value: $\delta x_{3}^{\prime}=\left(V_{D}-\delta x_{3}\right) / 2$.

In the region of spatial frequencies, the quantity $\delta x_{3}^{\prime}$ determines the measurement error of the spatial frequency

$$
\delta \nu_{x m}=\frac{V_{D}-\delta x_{3} .}{2 \lambda f}=\frac{V_{D}}{2 \lambda f}-\frac{1}{X_{m}} .
$$

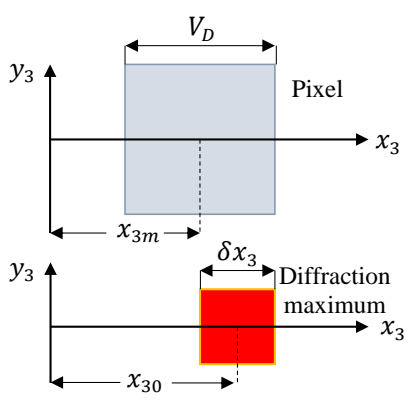

a

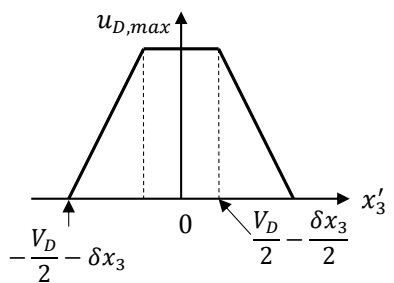

b
Fig. 5. Determination of the measurement error of spatial frequency: (a) is a position of the pixel and diffraction maximum in the plane $x_{3} y_{3}$; (b) is an amplitude of the pixel signal as a function of the position of the diffraction maximum.

\section{Conclusions}

1. Modern optical information processing systems, including coherent optical spectrum analyzers, use matrix space-time light modulators as an optical signal (image) input devices. The output signal is registered by matrix detector. However, in this case there are large distortions of the input signal caused by the matrix structures of the modulator and the detector. At the same time, there is lack of scientific and technical literature about distortions of input signals in such processors.

2. Physical and mathematical model of COSA, which uses a matrix modulator and detector, was developed. It allowed to get a general expression for the signal at the spectrum analyzer output. The study of it showed that

2.1. The type of signal at the MD output depends on the pixels size of the modulator and detector matrices, as well as on the aberrations and the diameter of the entrance aperture of the Fourier-lens. All this 
leads to significant distortion of the spectrum of the test signal;

2.2. The signal at the spectrum analyzer output is a convolution of an ideal signal spectrum with a discrete spatial transmission spectrum of the modulator, which is followed by convolution with a discrete sensitivity of the matrix detector. This means that the spectrum of the test signal is distorted by the spatial spectrum of the modulator and the matrix structure of the detector;

2.3. The important feature of the signal is its independence from the phase shift, which is caused by the displacement of the modulator center from the spectrum analyzer optical axis;

2.4. The signal at the MD output consists of an infinite number of diffraction maximums. Each of them has three maximums and the distances between them are proportional to the spatial frequency of the test signal;

2.5. The formulas for determining the spatial frequency (23) or (24) differ substantially from the traditional formula (4) and depend on the position of the central and lateral maximums in the first-order diffraction maximum;

2.6. The inaccuracy in frequency measuring is determined by formula (34) and depends on the pixel size, the focal length of the Fourier-lens and the size of the modulator matrix.

3. It is expedient to study the influence of the Fourier-lens point spread function on the general characteristics of the digital COSA in the future.

\section{References}

[1] Kolobrodov V. G., Tymchyk G. S. (2014) Prykladna dyfraktsiina optyka [Applied Diffractive Optics]. Kyiv, NTUU KPI, 312 p.

[2] Okan K.E. (2007) Diffraction, Fourier Optics and Imagi$n g$. Wiley \& Sons, 428 p. DOI:10.1002/0470085002

[3] Bogatyireva V.V, Dmitriev A.L. (2009) Opticheskie metody obrabotki informatsii [Optical Methods of Information Processing]. ITMO University, St. Petersburg, $74 \mathrm{p}$.

[4] Keysesent D. (1980) Optical processing of information. Mir Publ., Moscow, $350 \mathrm{p}$

[5] Kolobrodov V.H., Tymchyk H.S. and Kolobrodov M.S. (2015) Koherentni optychni spektroanalizatory [Coherent optical spectrum analyzer], Kyiv, Politekhnika Publ., 180 p.

[6] Kolobrodov V.G., Tymchik G.S. and Nguyen Q.A. (2013) The problems of designing coherent spectrum analyzers. Eleventh International Conference on Correlation Optics. DOI: $10.1117 / 12.2049587$

[7] Kolobrodov V.G., Tymchik G.S. and Kolobrodov M.S. (2015) The diffraction limit of an optical spectrum analyzer. Twelfth International Conference on Correlation Optics. DOI: $10.1117 / 12.2228534$

[8] Harvey J.E. (2009) Analysis and design of wide-angle foveated optical systems based on transmissive liquid crystal spatial light modulators. Optical Engineering, Vol. 48, Iss. 4, pp. 043001. DOI: 10.1117/1.3122006
[9] Kuz'min M.S. and Rogov S.A. (2015) Optical Fourier processor with a liquid-crystal information-input device. Journal of Optical Technology, Vol. 82, Iss. 3, pp. 147. DOI: $10.1364 /$ jot. 82.000147

[10] Driggers R.G., Friedman M.H. and Nichols J. (2012) Introduction to Infrared and Electro-Optical Systems. Artech House, London, 534 p.

[11] Vollmerhausen R.H., Reago D. and Driggers R.G. (2010) Analysis and evaluation of sampled imaging systems. SPIE, Washington, $288 \mathrm{p}$.

\section{Вплив модулятора і фотоприймача на вихідний сигнал оптичного спектро- аналізатора}

\author{
Колобродов В. Г., Тимчик Г. С., Микитенко В. I., \\ Колобродов М. С., Луцюк М. М.
}

У статті досліджується запропонована фізикоматематична модель когерентного оптичного спектроаналізатора (KOC), що використовуе в якості пристроїв введення та виведення сигналів матричного модулятора світла і приймача випромінювання. Ця модель дозволяє визначити спотворення у вихідному сигналі спектроаналізатора і похибки у визначенні просторової частоти досліджуваного сигналу. Дослідження цієї моделі показало, що вид сигналу на виході КОС залежить від розмірів пікселів матриць модулятора і приймача, а також від аберацій і діаметра вхідної зіниці Фур'є-об'єктива. Сигнал представляе згортку ідеального спектра вхідного сигналу з дискретним просторовим спектром пропускання модулятора з подальшою згорткою з дискретною чутливістю матричного приймача випромінювання. Це означає, що спектр досліджуваного сигналу спотворюється просторовим спектром модулятора і матричною структурою приймача випромінювання. Важливою особливістю сигналу $\epsilon$ його незалежність від фазового зсуву, який обумовлений зміщенням центру модулятора щодо оптичної осі спектроаналізатора. Вихідний сигнал КОС складається з нескінченного числа дифракційних максимумів, кожен з яких має три максимуми, відстань між якими пропорційна просторовій частоті досліджуваного сигналу. Положення (частота) максимумів визначається розміром пікселя, a їх ширина розміром модулятора. Отримано формули для визначення просторової частоти досліджуваного сигналу, які суттєво відрізняються від традиційної формули і залежать від положення центрального і бокових максимумів в дифракційному максимумі. Похибка вимірювання частоти залежить від розміру пікселя приймача, фокусної відстані Фур'є-об'єктива і розміру матриці модулятора. Розроблено методику визначення похибки вимірювання просторової частоти гармонійного сигналу. Похибка визначається як різниця між істинною частотою, що відповідає положенню центра дифракційного максимуму, і виміряної частотою, що відповідає положенню центра пікселя, який має максимальний сигнал.

Ключові слова: цифровий оптико-електронний спектроаналізатор; матричний модулятор світла; матричний приймач випромінювання; просторовий спектр зображення 


\section{Влияние модулятора и фотоприемни- ка на выходной сигнал оптического спектроанализатора}

Колобродов В. Г., Тимчик Г. С., Микитенко В. И., Колобродов Н. С., Луцюк Н. М.

В статье исследуется предложенная физикоматематическая модель когерентного оптического спектроанализатора (КОС), использующего в качестве устройств ввода и вывода сигналов матричный модулятор света и приемник излучения. Однако при этом возникают большие искажения входного сигнала матричными структурами модулятора и приемника. Предложенная модель позволяет определить искажения в выходном сигнале спектроанализатора и погрешности в определении пространственной частоты исследуемого сигнала. Рассмотрены модели основных составляющих KOC: матричного пространственного модулятора света, Фурье-объектива и матричного приемника излучения. Исследование этой модели КОС показало, что вид сигнала на выходе спектроанализатора зависит от размеров пикселов матриц модулятора и приемника, а также от аберраций и диаметра входного зрачка Фурье-объектива. Сигнал представляет собой свертку идеального спектра входного сигнала с дискретным пространственным спектром пропускания модулятора с последующей сверткой с дискретной чувствительностью матричного приемника излучения. Это означает, что спектр исследуемого сигнала искажается пространственным спектром модулятора и матричной структурой приемника излучения. Важной особенностью сигнала является его независимость от фазового сдвига, который обусловлен смещением центра модулятора относительно оптической оси спектроанализатора. Выходной сигнал $\mathrm{KOC}$ состоит из бесконечного числа дифракционных максимумов, каждый из которых имеет три максимума, расстояние между которыми пропорционально пространственной частоте исследуемого сигнала. Положение (частота) максимумов определяется размером пиксела, а их ширина - размером модулятора. Получены формулы для определения пространственной частоты исследуемого сигнала, которые существенно отличаются от традиционной формулы и зависят от положения центрального и боковых максимумов в дифракционном максимуме. Погрешность измерения частоты зависит от размера пиксела приемника, фокусного расстояния Фурье-объектива и размера матрицы модулятора. Разработана методика определения погрешности измерения пространственной частоты гармонического сигнала. Погрешность определяется как разность между истинной частотой, соответствующей положению центра дифракционного максимума, и измеренной частотой, соответствующей положению центра пиксела, который имеет максимальный сигнал.

Ключевые слова: цифровой оптико-электронный спектроанализатор; матричный модулятор света; матричный приемник излучения; пространственный спектр изображения 